Dr Stanko Pihler

profesor Pravnog fakulteta u Novom Sadu

\title{
O AKTUELNOM PROJEKTU SAVEZNOG ZAKONA O AMNESTIJI*
}

Poslednjih godina kod nas se, pre svega u okviru nekih nevladinih organizacija i povodom obaveza koje proističu iz Dejtonskog sporazuma, insistiralo na amnestiranju šireg kruga lica za, pre svega, neka krivična dela protiv Vojske Jugoslavije i neka krivična dela protiv osnova ustavnog uređenja i bezbednosti zemlje. Savezni Zakon o amnestiji iz 1996. g. nije bio dovoljan da adekvatno reši problem, jer je njime obuhvaćen uski krug lica (odnosio se na dva krivična dela i nije obuhvatio profesionalne vojnike). Zakon o amnestiji Republike Crne Gore iz 1999. g. je pitanje amnestiranja za širi krug vojnih krivičnih dela rešio relativno adekvatno, ali on nije saglasan saveznom Ustavu pošto se republičkim zakonom ne može amnestirati za krivična dela uređena saveznim krivičnim zakonodavstvom. S druge strane, iako je on primenjen, njegova (doduše neustavna) primena odnosila se samo na teritoriju Crne Gore!

Nakon oktobarskih događanja, intenzivno se pristupilo izradi projekta saveznog Zakona o amnestiji, sa uverenjem da ce to biti prvi zakon koji bi donela novoizabrana Savezna narodna skupština. Projekt je izrađen i dostavljen Saveznoj vladi. Međutim, nekako baš u vreme izrade ovog zakonskog projekta i informisanja strane i domaće javnosti o njemu, a kao posledica niza okolnosti, došlo je do širokih i oštrih pobuna (neki tvrde da je u pitanju sinhronizovana pobuna) lica lišenih slobode u našim kaznenim ustanovama, pre svega u tri velika kaznena zavoda. Pored ostalog, pobunjeni zatvorenici postavili su zahtev za opštom amnestijom lica lišenih slobode, u tom smislu da se svim licima lišenim slobode smanji kazna zatvora za trećinu. Resorno ministarstvo zaduženo za izvršenje krivičnih sankcija, odnosno tzv. koministri Ministarstva pravde republike Sr-

* Rad primljen: 10. XII 2000. 
bije, su u razgovorima sa osuđenicima javno prihvatili njihove zahteve $\mathrm{i}$ garantovali da će se izraditi projekat zakona o amnestiji. Nevolja je u tome što su oni mogli tu garanciju da pruže samo u odnosu na amnestiju povodom krivičih dela propisanih republičkim krivičnim zakonodavstvom, kao i u tome što u ovom momentu (do narednih izbora) nije moguće doneti nijedan republički zakon u Republici Srbiji, jer je Narodna skupština raspuštena.

S obzirom na zakonodavne nadležnosti federacije i republika, pitanje opšte amnestije može da se reši samo sinhronizovano na federalnom i republičkom planu, tj. da se istovremeno donesu i stupe na snagu savezni i republički zakoni o amnestiji. U protivnom problem ne bi bio principijelno dobro rešen i dodatno bi se čitava situacija oko opšte amnestije iskomplikovala.

Novonastala situacija postavila je na dnevni red pomenuti, već izrađeni i Saveznoj vladi dostavljen, Savezni zakon o amnestiji. Očigledno je bilo neophodno da se taj projekat proširi, u tom smislu što bi Zakon o amnestiji obuhvatio i pomenutu specijalnu amnestiju (za neka vojna krivična dela i za neka krivična dela protiv osnova ustavnog uređenja i bezbednosti zemlje), ali i opštu amnestiju, tj. amnestiju svih lica osuđenih na kaznu zatvora. U tom smislu je Savezno ministarstvo pravde izradilo nov (,prošireni”) projekat Zakona o amnestiji, koji obuhvata kako lica pod opštom tako i lica pod „specijalnom” amnestijom. Međutim, u međuvremenu, tj. ovih dana, Republika Crna Gora je donela svoj zakon o opštoj amnestiji, pa je time preduhitrila opšte amnestiranje, kako ono na saveznom tako i ono na nivou Republike Srbije. Istovremeno, otvara se pitanje pred novim amnestiranjem na saveznom i nivou Republike Srbije, da li prihvatiti isti ili različit stepen (sadržinu) opšteg amnestiranja koje je već prihvaćeno Zakonom o amnestiji Crne Gore, ili naći drugačija rešenja. Ako bi se i prihvatila ista sadržina amnestiranja, to ne otklanja problem koji nastaje u vezi sa različitim vremenom stupanja na snagu pojedinih zakona o amnestiji.

Predlog novog Saveznog zakona o amnestiji, dakle, obuhvata, pre svega, opštu amnestiju svih lica kojima su pravnosnažnom presudom izrečene kazne zatvora, kao i ,specijalnu” amnestiju povodom nekih krivičnih dela. Dejstvo jednog i drugog vida amnestije koja se ovim projektom zakona predlaže - nije isto. Opšta amnestija bi obuhvatila sva lica kojima su pravnosnažnom presudom izrečene kazne zatvora do 7. oktobra 2000. g., u tom smislu da se oslobađaju od izvršenja jedne četvrtine izrečene kazne. „Specijałna” amnestija bi se odnosila na lica koja su učinila, odnosno za koja postoji osnovana sumnja da su učinila sledeća krivična dela: odbijanje primanja i upotrebe oružja, neodazivanje pozivu i izbegavanje vojne službe, izbegavanje vojne službe onesposobljavanjem ili obmanom, samovoljno udaljenje i bekstvo iz Vojske Jugoslavije, izbegavanje popisa i pregleda i neizvršavanje materijalne obaveze, ako su učinjena do 7. oktobra 2000. g., kao i lica koja su učinila, odnosno za koja postoji osnovana sumnja da su učinila sledeća krivična dela: sprečavanje borbe 
protiv neprijatelja, oružana pobuna, pozivanje na nasilnu promenu ustavnog uređenja, udruživanje radi neprijateljske delatnosti i povreda ugleda SRJ, a pod uslovom da su učinjena u periodu od 27. aprila 1992. g. do 7. oktobra 2000. g. Dejstvo „specijalne” amnestije bi obuhvatilo: aboliciju pomenutog kruga lica, obustavu postupaka koji su u toku, oslobođenje od daljeg izdržavanja kazne ako je ono u toku odnosno odustajanje od izvršenja ako još nije u toku i ukidanje pravnih posledica osude koje se sastoje u sticanju određenih prava.

Motivi za opštu i motivi za „specijalnu” amnestiju nisu identični. Prema tvorcima projekta ovog Zakona, opšta amnestija u ovom momentu ne bi trebalo da bude motivisana pobunama lica lišenih slobode u kaznenim ustanovama, već dubljim razlozima, kojima su uostalom i same pobune određene. Pobune bi bile samo povod, a ne i razlog opšte amnestije. Treba otvoreno i iskreno priznati da javno mnenje, političke partije i državne institucije dugo nisu vodile dovoljno računa o tome šta se zbivalo u našim kaznenim ustanovama. Opšte stanje u njima je već godinama alarmantno, ali je trebalo da dođe do šire narodne pobune protiv režima koji je doveo do opšteg rasula institucija pa da se ta opšta pobuna praktično proširi i na osuđeničku populaciju. Ta populacija je mnogo informisanija, zrelija i uključenija u opšta društvena kretanja nego što se to pretpostavlja. Tok samih pobuna (ili pobune) to pokazuje. Ova je populacija reagovala legitimno, jer je jednako kao i ostali građani, a ako ne i više, bila pogođena opštim stanjem. Zato je i njihov zahtev za amnestijom, i to opštom, legitiman. Do ove pobune je očigledno moralo doći da bi se konačno skrenula pažnja šire javnosti i političkih i državnih institucija na ovaj segment našeg socijalnog uređenja. Bilo bi bolje da se desilo obrnuto, tj. da su reagovale same institucije, ali to se ipak nije desilo. Ovim prihvatamo da su i kaznene ustanove deo opšteg sistema institucija i da je osuđenička populacija deo našeg građanstva koji se ne sme zaboraviti u ovim burnim vremenima. Prema tome, treba prihvatiti načelan zahtev za opštim amnestiranjem, ali takođe priznati da je amnestija potrebna i iz širih razloga. Razlozi za opštu amnestiju su: politički, kriminalno-politički, penološki, pravno-politički i moralni.

Opšta politička klima mora da se menja u svim svojim segmentima i u svim segmentima društva. Mora se izraziti politička volja za institucionalizacijom društva, a to znači i da se sve što je rđavo u postojećim institucijama popravi. Građani koji su lišeni slobode zbog učinjenih krivičnih dela deo su opšteg narodnog korpusa pa je neophodno i prema njima izraziti jedan načelni gest dobre volje. To je ujedno gest tolerancije i skretanja pažnje na njih, akt njihove demarginalizacije i destigmatizacije. Taj gest bi se izrazio kroz opštu amnestiju u smislu linearnog smanjivanja kazne svim osuđenim licima do određenog nivoa. Nivo mora biti primeren, jer ovaj akt amnestije mora biti ozbiljan i odgovoran prema svakom. Taj gest bi povoljno uticao i na opštu društvenu klimu i ublažavanje tenzija u društvu. 
Kriminalno-politički razlozi nalažu potrebu opšte amnestije u ovom momentu iz generalno-preventivnih i specijalno-preventivnih razloga. Specifičnim izražavanjem poverenja u ljude koji su otuđeni za krivična dela, u smislu da se i smanjenim nivoom izrečenih kazni može ostvariti svrha kazne, deluje ne samo specijalno-preventivno već i generalno-preventivno, pogotovo u uslovima kada je tamna brojka kriminaliteta u društvu previsoka i za svakog očigledna, pa je pravosuđe već iz tog razloga fragmentarno primenjivailo krivično pravo. Pravosuđe, sa svoje strane, ovim aktom ne bi trebalo da bude pogođeno, jer je i ono svesno u kakvim je uslovima radilo, kao što su toga bili svesni i građani.

Penološki razlozi za amnestijom su posebno značajni, naročito zbog situacije nakon pobune, ali i inače. Amnestijom bi složeni proces uspostavljanja normalnog stanja u kaznenim ustanovama mogao biti pospešen. One time postaju legitimnije i za same osuđenike. Amnestija bi smekšala opštu potištenost i onih koji u njima rade, ali i emocije kod osuđenika jer ostavlja utisak dobronamernosti i iskrenosti vlasti. Više je šanse da bi se amnestijom motivisali i sami osuđenici da učestvuju u procesima stabilizacije stanja u ovim ustanovama. Da bi se postigao pun efekat ove vrste mora se istovremeno i hitno postaviti pitanje odgovornosti za stanje u kaznenim ustanovama i izvršiti temeljite kadrovske promene. Ako se to ne učini, efekti amnestije, posebno u penološkom smislu, neće biti adekvatni.

Pravno-politički, posebno kazneno-politički razlozi takođe nalažu potrebu opšte amnestije u ovom momentu. Oni su vezani za uspostavljanje racionalne krivično-pravne, a posebno kazneno-pravne politike. Aktom opšte amnestije bi se indirektno priznala neosmišljena i represivna kaznena politika, koja je bila sastavni deo pojačane represijalizacije društva. Ako ta politika slabi na opštem planu - mora se izraziti i na ovom specifičnom.

Moralni razlozi za opštu amnestiju proizilaze iz činjenice da je legitimno tvrditi, da su osuđenici u periodu opšteg lošeg materijalnog stanja društva (pa i moralnog stanja) bili snažnije izloženi nedaćama, zbog čega je kazna za njih bila obeležena snažnijim intenzitetom zla nego inače. Tako bi se njeno celovito izvršenje moglo s razlogom smatrati nepravičnim. Zato taj pojačani intenzitet zla u kazni treba putem amnestije da anulira jedan njen deo.

„Specijalna” amnestija je motivisana, manje-više poznatim posebnim razlozima. O njima je bilo dosta govora u različitim debatama o potrebi amnestiranja za neka, posebno vojna krivična dela i u odnosu na, pre svega mlade ljude koji su se našli u vrtlogu ratova i opšteg haosa u društvu. Ogroman je broj mladih ljudi podvrgnut krivičnom progonu (ili bi to mogao biti) za ova krivična dela. Na desetine hiljada je, zbog toga, izbeglo iz zemlje. Mnogo od njih je, zbog svog ličnog odnosa prema ratnohuškačkoj politici koja je ovde godinama vođena, radije prihvatilo dobrovoljni egzil, odnosno specifičnu pobunu protiv takve politike. Njih i iz 
moralnih i iz političkih i iz socijalnih razloga treba amnestirati na način kako je to napred rečeno.

Treba naglasiti, da ovakvim pristupom amnestiji u ovom momentu, nikako ne bi smelo da se amortizuje primena ostalih ustanova krivičnog prava, kojima je cilj ispravljanje nepravdi, otklanjanje grešaka u vođenju krivičih postupaka ili postizanje određenog (konkretnog) penološkog cilja, kao što su pomilovanje, vanredni pravni lekovi, uslovni otpust. Ove ustanove, posebno pomilovanje, moraće se primenjivati možda i intenzivnije nego inače, pored ostalog i zbog toga što se amnestijom, kao opštim aktom, ne mogu obuhvatiti svi problemi ove vrste koji stoje pred našim društvom i njegovim pravosudnim i političkim institucijama. 